УДК 656.222.4

Acn. А.О. Любченко

Postgraduate A.O. Liubchenko

\title{
АНАЛІЗ ПІДХОДІВ ДО УПРАВЛІННЯ ПРОПУСКНОЮ СПРОМОЖНІСТЮ ЗАЛІЗНИЦЬ
}

\author{
ANALYSIS APPROACHES TO MANAGEMENT \\ OF RAILWAYS CARRYING CAPACITY
}

\author{
Представила д-р техн. наук, професор Т.В. Бутько
}

\begin{abstract}
Актуальність. Однією 3 важливих задач функціонування залізничного транспорту $\epsilon$ отримання максимального ефекту в умовах раціонального використання його потужностей, безумовне, успішне вирішення задач із впровадження інноваційних технологій та підходів для реалізації пропускної спроможності.

У сучасних умовах на Україні провізна спроможність залізниць задіяна на $50 \%$. Відповідно до цього у 2012 році вона склала 51 млн тонн - лише 50\%, від можливого щорічного вантажообігу у 100 млн т. Зокрема при вдосконаленні управління пропускною спроможністю можливо досягнути нових результатів. Для розвитку транзитних перевезень Укрзалізниця підвищує пропускну спроможність окремих ділянок, швидкість транспортування, вводить автоматизовані системи для скорочення перевізного процесу.

В цій науковій роботі проводиться порівняльний аналіз європейської системи 3 урахуванням та взаємодією іiі підсистем між собою, наводиться приклад української системи у порівнянні. Таким чином управління пропускною спроможністю в умовах транспортного ринку стає актуальним завданням.
\end{abstract}

Аналіз світового досвіду. Одну 3 найдосконаліших систем управління залізницею було розроблено у Швеції, ця система розширила можливості застарілої системи Train Plan. Обробка заявок компаній-операторів на виділення пропускної спроможності являє складну задачу для менеджерів інфраструктури. Ії складність обумовлена великою кількістю каналів надходження заявок на виділення ниток графіка, необхідністю їх обробки 3 вводом в базу даних та підтримки зворотного зв'язку з метою інформування про статус поданих заявок. Для цього компанія Vossloh IT розробила систему AccessPlan, яка використовується як для довгострокового, так i для короткострокового планування інфраструктури.

AccessPlan являє собою електронну систему управління заявками на нитки графіка та пропозиціями, засновану на гнучкій технології використання Webсервісів і документів формату XML/SOAP. Вона дозволяе адміністраціям інфраструктури отримувати та обробляти заявки, використовуючи клієнтські Webпрограми. Система дозволяє клієнтам контролювати статус своїх запитів та аналізувати графіки, які відповідають їх потребам.

Нова система AccessPlan розширяє можливості системи TrainPlan та інтегрується в неї. Якщо TrainPlan підтримує процедуру складення графіка руху поїздів, то AccessPlan являє собою систему електронного управління попитом та пропонуванням, яка основана на технології Web- сервісів. 
За останні 10 років пройшли значні зміни в методах експлуатації залізниць в Свропі, де діє Директива 91/440/СС Європейського союзу. Якщо раніше залізниці країни контролювала одна адміністрація, то тепер при складанні графіка руху беруть участь адміністрації, які керують інфраструктурою та компаніїоператори перевізники. Оператори діють інколи на умовах короткострокових «франшиз», для них важливо брати участь в процесі планування та розподілення пропускної спроможності, при цьому використовувати механізм голосування. AccessPlan забезпечує такий механізм у формі структури для передачі даних графіків руху, стандартизації їх змісту та надавання адміністраціям інфраструктури можливості контролювати цей процес, при цьому надає прозорість для компанійоператорів.

Більшість країн Свропейського простору застосовують певні правила та методи управління, які повинні забезпечуватись Директивою 91/440/СС. Ця директива регламентує існування компаній 3 функціями забезпечення експлуатації залізниць (наприклад, адміністрації інфраструктури, які відповідають за поточний стан та доступ до неї) та компаній - операторів перевізників (задачею яких $є$ організація руху поїздів та роботи поїзних бригад). Вони повинні працювати злагоджено, щоби створити надійний графік руху поїздів.

Наочний приклад можна навести для основних міжміських перевізників в Європі:

- Intercity-Express

(Германія, Голландія, Бельгія, Франція, Швейцарія та Австрія);

- Thalys (Франція, Германія, Бельгія, Голандія);

- Enterprise

(Ірландія

Ta

Великобританія);

Бельгія);

- Eurostar (Великобританія, Франція,

- EuroCity (вся Западна та Центральна Європа, за виключенням Ірландії та Великобританіі);

- TGV (Франція, Бельгія, Італія, Швейцарія, Германія);

- Oresundtrain (Данія, Швеція).

При розрахунку пропускної спроможності в Свросоюзі кількість поїздів розраховується за такою формулою:

$$
\mathrm{K}=\mathrm{q}_{\max } \cdot n,
$$

де К - пропускна спроможність дільниці;

$\mathrm{q}_{\max }$ - максимальна інтенсивність;

n - кількість поїздів на колії.

Під час розрахунку проводиться аналіз балансу пропускної спроможності, це ми можемо побачити з рисунка.

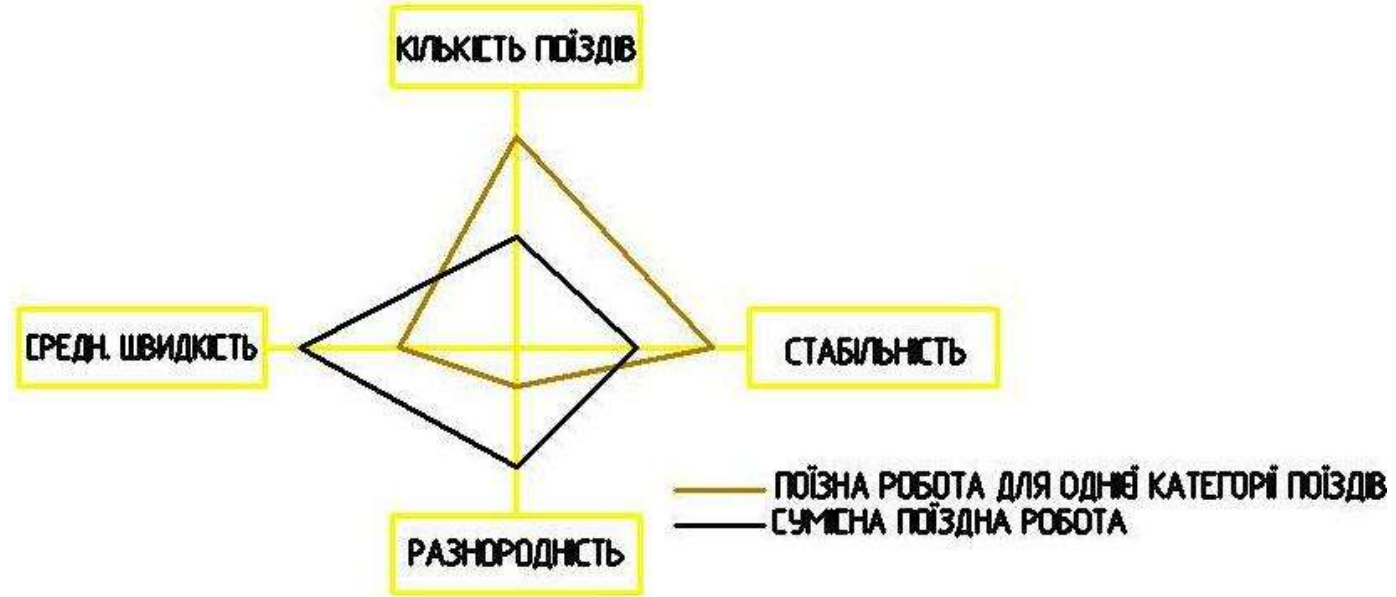

Рис. Баланс пропускної спроможності (Швеція) 
Рисунок показує, що пропускна спроможність балансує від кількості поїздів, стабільності графіка руху, середньої швидкості та різнорідності поїзного складу. Аналізуючи рисунок, можна зробити такі висновки: якщо потрібно збільшити швидкість та збільшити пропускну спроможність на дільниці, потрібно привести поїзну роботу до однієї категорії.

Для інтегрованих операторів (які управляють залізницею та організовують рух поїздів ) така задача являє собою інтерактивний процес прийняття рішення на основі аналізу попиту на перевезення й можливостей експлуатації в рамках використовування доступних ресурсів. Цей процес потребує організації зв'язку між підрозділами однієї структури.

В тих випадках, коли адміністрація інфраструктури та компанії-перевізника $\epsilon$ незалежними організаціями, обмін даними між ними дуже часто $є$ цілою проблемою, при використанні різних інформаційнокеруючих систем.

AccessPlan дозволяє адміністраціям інфраструктури раціоналізувати процедури, як довгострокового, так і короткострокового планування, використовуючи тільки один формат для подачі заявки та отримання відповідних пропозицій на нитки графіка. Ця система забезпечує наочність операторам під час подачі заявок на отримання пропозиції. За допомогою цієї системи в Швеції було досягнуто значного результату щодо реалізації пропускної спроможності.

В 1990 роках в Євросоюзі пройшла реструктуризація залізниць. Вони були об'єднані в систему ETCS.

Програма експлуатації включає в себе такі елементи:

- змішаний рух поїздів, які використовують як ETCS рівня 2, так і точкову АЛС РZВ;

- 32006 року організовувано допоміжний рух поїздів, використовуючи АЛСН LZB;
- рух поїздів починається в режимі точкової АЛС РZВ (активний модуль STM), в подальшому перехід в режим ETCS, a також перехід з STM на ETCS 2 рівня виконується автоматично при прослідуванні світлофорів;

- сигнальні показники перетворюються в задані величини ( задана швидкість, дозволена швидкість в місці перешкоди) та відображаються на пульті керування машиніста локомотива.

У червні 2005 року почались експериментальні тестування системи ETCS 2 рівня, направлені на перевірку іiі безпеки. Після вдалого тестування та отримання від ЕВА допуску системи в грудні 2005 року почався регулярний рух поїздів з використанням ETCS. У травні 2006 року було підвищено максимальну швидкість руху поїздів на гілці Берлін Лейпциг до 200 км/год.

Окрім високошвидкісних ліній, впроваджувати ETCS економічно доцільно тільки на лініях DBAG, що входять в коридори міжнародних вантажних перевезень. Це в першу чергу лінії Еммерих - Базель і Ахен - Франкфурт-на-Одері. Тут ETCS встановлюватиметься паралельно використовуваній нині точковій АЛС РZВ. Аналіз вартості цих проектів ще не завершений, питання фінансування 3 федерального бюджету i бюджету ЄC недоопрацьовувалися.

На пілотній ділянці ЙютербогГалле/Лейпциг залізниць Німеччини (DBAG) встановлена європейська система управління рухом поїздів ETCS. У грудні 2005 р. система ETCS введена в постійну експлуатацію, і почалися випробування системи на надійність.

Із вводом в експлуатацію системи на лінії Йютербог - Галле/ Лейпциг в Германії почала працювати перша залізнична лінія, облаштована новою європейською системою управління рухом поїздів ETCS.

Метою проекту $\epsilon$ можливість впровадження ETCS на DBAG в експлуатацію, враховуючи безпеку системи 
та доведення іï до комерційного використання на пілотній лінії зі швидкістю руху поїздів 200 км/год, а також використання накопиченого попиту для уточнення специфікацій ETCS, що особливо важливо для майбутніх проектів DBAG у світлі директив Європейського союзу 96/48 та 2001/16, налаштованих на створення високошвидкісних ліній та транс'європейської мережі.

Виникнення проблем у діяльності та розвитку залізничного транспорту в Україні зумовлене рядом негативних факторів, зокрема:

- прогресуючим старінням основних фондів. Загальний ступінь зносу основних фондів становить $56 \%$, у тому числі рухомого складу - $68 \%$. Потребує істотної модернізації інфраструктура залізниць. Протяжність колій, ремонт яких не проведено своєчасно, досягла $30 \%$ загальної протяжності. Внаслідок цього обмежується швидкість руху поїздів, створюється реальна загроза безпеці руху на залізничному транспорті, виникнення техногенних катастроф;

- відсутністю державної підтримки інноваційного розвитку галузі та недосконалістю законодавчої бази у частині залучення інвестицій;

- низькими тарифами на перевезення пасажирів і відсутністю дієвого механізму компенсації збитків під час надання суспільних послуг, що призводить до перехресного субсидування збиткових пасажирських перевезень за рахунок вантажних. Збитки від таких перевезень тільки у 2005 році перевищили 2 млрд гривень, що значно обмежує можливість техніко-технологічної модернізації залізничного транспорту.

Залізничний транспорт України займає четверте місце у світі після Росії, США і Канади за обсягом вантажообігу. У 1996 р. залізницями перевезено близько 300 млн. т вантажів і 540 млн люд пасажирів. При цьому обсяги перевезень, як вантажів, так і пасажирів, постійно скорочуються. У структурі перевезення вантажів переважають вугілля, в тому числі кокс, руди чорних та кольорових металів і самі метали, лісові вантажі, будівельні матеріали, а саме: цемент, машини та устаткування, продукція АПК.

Залізничний транспорт працює на межі можливостей, оскільки його виробнича база фізично спрацьована i морально застаріла, Україна поки що не має власного виробництва магістральних електровозів, пасажирських вагонів, хоч має всі необхідні передумови для розвитку цього виробництва. Імпорт названих транспортних засобів обмежується відсутністю коштів.

У розгляді транспортного комплексу України варто приділити увагу розміщенню даного виду транспорту та його регіональним відмінностям.

Що стосується густоти сітки залізничних колій, то в Україні ця цифра коливається від 40 до 80 км на 100 км² $^{2}$ цей показник досить високий для світових масштабів. Однак, якщо говорити про регіональне розміщення, то не всі області України мають достатньо розвинуту залізничну вітку.

Важливим $\epsilon$ південно-західний напрямок, інтенсивні вантажо- i пасажиропотоки якого пов'язані 3 перевезенням імпортно-експортних вантажів 3 України, а також вантажів 3 Росії, Білорусі у чорноморські порти і у зворотному напрямку; пасажирів, які їдуть на відпочинок і лікування на курорти Криму, Причорномор'я та Приазов'я.

В Україні розрахунок пропускної спроможності розраховується за формулою

$$
\mathrm{N}_{\text {Дв }}=\frac{1440-t_{\text {TЕХ }}}{T_{\text {ПЕР }}} \alpha_{\text {РАД }} K,
$$

де $\mathrm{t}_{\text {тех }}-$ час технологічного вікна для виконання ремонтних робіт на ділянці.

$\alpha_{\text {над }}-$ коефіцієнт надійної роботи технологічних засобів;

К - кількість поїздів у пакеті;

$\mathrm{T}_{\text {пер }}-$ період графіка. 
Метою даного аналізу є підвищення ефективності використання пропускної спроможності на залізницях України, а також вихід нових послуг на ринок, таких як впровадження реалізації пропускної спроможності. Потрібно виявити особливості існуючих теоретичних підходів та провести досконалий аналіз вже створених систем 3 реалізації пропускної спроможності в Європі.

Висновки. Основний акцент у статті зроблено на порівнянні європейських систем. Зараз актуальним $є$ питання вдосконалення роботи транспортних коридорів на території України та створення нових галузей інфраструктури.
Український транспортний ринок потребує значних змін, впровадження такого поняття, як комерційна пропускна спроможність забезпечить нову транспортну послугу. Вона буде інноваційною на території України, а забезпечуватись буде при реалізації ниток графіків для загальних користувачів транспортних послуг. Система управління на залізниці не досконала, основна мета аналізу була направлена на вдосконалення вже існуючих систем, що використовуються в Європі. Одна 3 основних задач - це створення в майбутньому нової послуги 3 виходом на транспортний ринок України.

\section{Список літератури}

1. Данько, М.I. Удосконалення планування використання інфраструктури залізниць операторськими компаніями на основі ресурсозбереження [Текст] / M.I. Данько, В.В. Кулешов, М.П. Носенко // Вісник економіки транспорту і промисловості. - Харків: УкрДАЗТ, 2007. - Вип. 19-20. - С. 230-233.

2. Левин, Д.Ю. Расчет и использование пропускной способности железных дорог [Текст] / Д.Ю. Левин, В.Л. Павлов. - М., 1981. - 398 с.

3. Hansen, S., Landex, A. \& Kaas, A.H., The Network effects of Railway Investments, Proc. of the 10th International conference on Computers in Railways, [Електронний ресурс] eds. J. Allan, C.A. Brebbia, A.F. Rumsey, G. Sciutto, S. Sone \& C.J. Goodman, 2006.

4. The Swedish rail network, 1997, [Електронний ресурс] Banverket Planeringsavdelingen, Sweden (in Swedish).

5. Höllmüller, J. \& Klahn, V., Implementation of the UIC 406 capacity calculation at Austrian railways (ÖBB). Proc. Of the 1st International Seminar on Railway Operations Modelling and Analysis, [Електронний ресурс] eds. I.A. Hansen, F.M.Dekking, R.M.P. Goverde, B. Hindergott, L.E. Meester, The Netherlands, 2005.

Ключові слова: управління, аналіз, підхід, залізничний транспорт.

\section{Анотаціiі}

У статті розглянуто основні існуючі системи управління на залізницях Євросоюзу. Проведено порівняльний аналіз української системи управління залізницею $з$ європейською системою.

В статье рассмотрены основные существующие системы управления на железных дорогах Евросоюза. Проведен сравнительный анализ украинской системы управления железнодорожным транспортом и европейской систем.

The article describes the main control system which used in European Community. An analysis is conductedtion between Ukrainian control ystem by the railway transportand European system. 